\title{
The Influence of Online Technology on the Performance of MSMEs in the Covid-19 Pandemic Era
}

\author{
Nurlinda ${ }^{1}$, Junus Sinuraya ${ }^{2}$, Asmalidar $^{3}$ \\ \{nurlinda@polmed.ac.id ${ }^{1}$,junus.sinuraya2012@gmail.com², asmalidar72@gmail.com ${ }^{3}$ \}
}

Politeknik Negeri Medan, Indonesia ${ }^{1}$, Politeknik Negeri Medan, Indonesia ${ }^{2}$, Politeknik Negeri Medan, Indonesia $^{3}$

\begin{abstract}
This study aims to analyze the effect of online technology on the performance of Micro, Small and Medium Enterprises (MSMEs) in the Covid-19 pandemic era. The outbreak of the corona virus has an impact on all aspects of the life of the Indonesian people and has even hit the economy sector at large, including MSMEs. MSMEs have limited use of technology. This has further exacerbated the performance of MSMEs coupled with government policies in dealing with Covid-19 such as staying at home, social distancing and reducing activities outside the home, ultimately causing a decrease in MSME income. This research is a quantitative study using primary data. The population and sample of this research were all UMKM culinary rujak as many as 40 . Data collection using a questionnaire. Data were analyzed using statistical descriptive analysis with simple linear regression. The results of the study found that there was an effect of the use of online technology on the performance of MSMEs. The implementation of this research is to provide input on alternatives that can be chosen by MSMEs during the Covid-19 Pandemic to maintain and improve their performance through the use of online-based technology.
\end{abstract}

Keywords: Information technology, online applications, MSMEs, performance

\section{Introduction}

Many Micro, Small and Medium Enterprises (MSMEs) are engaged in the culinary sector. Opening a business that is easy and does not require large capital attracts people to become entrepreneurs. Another factor is the change in people's lifestyles with a high level of busy mobility in the end, the working community prefers everything that is practical and fast [1] . This change in behavior becomes a new business opportunity that causes the culinary business to develop. The culinary business starts from the establishment of cafes, restaurants and also street vendors. However, currently MSMEs are experiencing a period of uncertainty due to the outbreak of the Covid-19 pandemic. The existence of government policies related to the Covid-19 pandemic, such as prohibiting people from leaving their homes, social distancing and carrying out lockdowns / quarantine areas, ultimately became a nightmare for business actors, especially MSME players, which caused business performance to disrupt. The lockdown action in response to the spread of the new corona virus ultimately threatens the existence of many innovative startups [2].

The phenomenon that occurs in the activities of MSME actors is a decline in performance in the form of turnover. Currently, one of the marketing strategies that can support MSMEs to survive in times of uncertainty is the use of online technology, including the use of online application services such as go-food / grab-food. The rapidly changing business environment has an impact on increasingly competitive competition as a result of technological developments [3], especially during the Covid-19 pandemic. The rapid 
development of technology that gave birth to smartphones as well as the development of internet and web-based businesses has finally become a new hope for MSMEs players to survive difficult times. The emergence of smartphones supported by internet services today is not only useful as a medium of information, but can also be a means of conducting trade transactions by utilizing electronic commerce (e-commerce) facilities. The development of ecommerce ultimately makes it easier for business people to conduct business transactions even though they are not face to face, including the MSME business.

The UMKM adopts an online application for business continuity. This decision not only provides opportunities for MSME players to add customers, but also provides convenience for the customers themselves. One of the benefits obtained by MSME players is the opportunity to expand the business by providing the widest possible access to innovate on the products offered without large capital to distribute them [4]. Other advantages when MSMEs use online applications are getting business promotion opportunities through applications, expanding market / customer segments, ease of product distribution to customers, having access to customers through applications, and avoiding shipping costs even though the impact is higher selling prices. The use of this online application eventually becomes a media for promotion and sales transactions that help entrepreneurs reach customers and expand market share, given the far-reaching reach that online applications such as Go-food / Grab-Food can do. Entrepreneurs nowadays can't just wait for customers to come to the store / outlet. In the end, this condition must be addressed by providing online sales services. Business actors must understand the conditions of their prospective customers in order to decide to buy and must be able to ensure customer satisfaction with the services provided so that these customers are satisfied and decide to buy [5]. In the end, the goal of getting closer to customers becomes realistic when this is done using online applications. The use of online technology is currently present and provides opportunities for businesses to approach customers and bring customers into the company in an effort to explore customer interests in new ideas / products and pretest customer interests [6]. In the end, the implementation of e-commerce, which includes online application services, will have a significant impact on every level of business strategy [7].

The results of several studies have found that there is an effect of technology on the performance of MSMEs[8], and through the adoption of e-commerce technology also affects the performance of MSMEs [9]. Another study found the effect of online marketing strategies on increasing MSME profits [10]. The research results of [4] found that the factors that encourage MSMEs to adopt online applications are to expand the business area and reach consumers who cannot come directly to the store, besides this online application is a medium for product marketing as well as a ways to increase sales turnover. The results of the research by Mumtahana et al [11] found that utilizing e-commerce technology fulfills product marketing strategies which can have an impact on increasing sales. Indraswarri \& Kusuma [12] found that there were differences in income before and after using online applications. Amelia (2019) found that there was a positive influence on the use of online go-food applications on increasing sales.

Rujak Sentir UMKM actors are a group of MSMEs engaged in micro business. Micro businesses based on law No. 28 Tahun 2008 [13] concerning MSMEs are productive businesses owned by individuals and / or individual business entities that meet the criteria for micro-businesses as regulated in law. The spread of the corona virus also has an impact on the performance obtained by these MSME players. from the lack of customers, the decline in turnover to the closure of the business had to be done due to the difficulty of the economy. Therefore, this study was conducted to analyze whether the use of online applications can 
maintain the performance of MSMEs. The performance included in this research is related to sales.

\section{Literature Review}

\subsection{Electronic Commerce (e-commerce)}

Electronic commerce (e-commerce) is narrowly defined as the act of trading using the Internet as a distribution channel in activities to market and sell goods and services to customers [7].A broad definition is presented by Malcolm [14] who explains that electronic commerce is the exchange of information about electronic payment goods / services and includes the creation and maintenance of web-based relationships. Referring to the above explanation, Fruhling \& Digman [7] electronic commerce is not limited to the Internet, intranet, extranet, electronic data exchange (EDI), etc. but the entire online transaction process, such as processing transactions with electronic payments, coordination with business partners. (inventory management), customer self-service (such as orders).

\subsection{Online Technology}

Online technology, including the use of online applications, is a technology that has emerged due to the most transforming findings of the present century, namely the internet (The-Economist, 1999). The presence of the internet is believed to be the basis for changing the business paradigm which has the potential to affect every link in the company's value chain [15].

The use of web media, including the use of online applications, is carried out by customers for making payments, advertising and promotions. The effectiveness of using online applications can be interpreted as how effective the process of online applications is to increase sales. The use of online applications (e-marketing) is an act of using the web in marketing products and services to customers [16]. Using online applications, the company's goals will be directly accessed by potential customers who use the application. all information provided by the company will be accessible to potential customers in realtime. Thus the use of online applications will streamline the activities that are the company's goals.

The use of online applications will affect business operations and marketing to customers. The effect of online applications occurs through three marketing channels, namely, "communication channels (information channels on product / service availability), transaction channels (facilitating economic exchange between buyers and sellers), distribution channels (facilitating physical exchanges[17]. The online application makes it easy for users to access information anywhere via a device connected to the internet. The indicators used regarding online applications consist of, (1) Promotion and (2) Distribution [18].

\subsection{Performance}

Performance is interpreted as a level to meet expectations associated with its function [19]. This expectation is related to its function in the organization. Managerial performance is "one of the factors that can increase organizational effectiveness". Manager performance is "the ability of managers to carry out their responsibilities in product quality, product quantity, product timeliness, new product development, personnel development, budget achievement, cost reduction (increased revenue), and public affairs" [20] 
The purpose of organizational effectiveness shows how important business performance is. Furthermore, company performance according to Soininen et al [21]is an indicator of high profitability and market share growth where the growth of the two measurement indicators is an essential part of company performance and is used to evaluate the competitiveness of the company. In general, there are two indicators that describe business performance as part of (a) financial performance (eg, sales increase performance, profitability, etc.); (b) operational performance (growth in market share, new products, product quality, marketing effectiveness and value added [22]. Financial performance is the extent to which financial efficiency and profit measure. Meanwhile, non-financial performance is operational performance that includes "customer satisfaction; sales growth; employee growth; market share [23]). The performance indicators used in this study consist of "sales growth; customer growth; profit growth; working capital growth [24].

\subsection{Micro, Small and Medium Enterprises (MSMEs)}

The definition of Micro, Small and Medium Enterprises (MSMEs) according to the Law of the Republic of Indonesia Number 20 of 2008 concerning Micro, Small and Medium Enterprises states that micro enterprises are productive businesses owned by individuals and / or individual business entities that meet the criteria of micro businesses as regulated in law. A small business is a productive economic business that stands alone, carried out by an individual who is not a subsidiary, not a branch of a company that is owned, and is not a direct or indirect part of a medium or large business. Medium-sized enterprises are productive economic enterprises that are independent, carried out by individuals who are not subsidiaries, are not owned branches of companies, and are not a direct or indirect part of a small or large business.

Referring to the number of assets and turnover, the criteria for SMEs consists of;

1. Micro enterprises have a maximum asset of 50 million and a maximum turnover of 300 million;

2. Small businesses have Assets larger than 50 million up to 500 million and turnover greater than 300 million up to $2.5 \mathrm{M}$; and

3. Medium enterprises have assets greater than 500 million up to $10 \mathrm{M}$ and turnover of large from $2.5 \mathrm{M}-50 \mathrm{M}$

\subsection{Go-Food/ Grab- Food}

Go-Food / Grab-food is a company engaged in the service sector [1].According to Tjiptono [25] a service company is an act of selling activities, providing benefits, offering satisfaction [1], and an act of offering other parties something that is intangible and does not result in ownership of something Umar [26]. Go-Food / Grab-food services are managed by vendors who sell applications via smartphones. The features offered basically include media promotions and online ordering where the agreed profit share ranges from $15 \%-20 \%$. GoFood / Grab-food is a food delivery feature. This feature is most often used by most customers every day to make transactions to buy the desired food from the intended outlet.

\subsection{The Effect of Online Application Utilization on MSME Performance}

The results showed that there was a positive influence on the application of online applications on business value [27]. Doherty, Ramsey, Harrigan, \& Ibbotson [28] found that "MSMEs that adopt and use broadband internet technology encourage efficiency and daily strategic developments. Arisandi [29] found that using e-commerce was able to increase business productivity and business endurance and increase sales. Utomo's [30] research found 
that the use of businesses using online technology can improve business performance. Research conducted by Misnawati \& Yusriadi [31] explains that opportunities for advanced digital technology will have an impact on the ease of managing a business to increase sales profits, while Zulfikar and Supriyoso [32] found that online sales are effectively carried out well. Hartmann \& Lussier [33]conducted research on the use of B2B to help sales during the Covid-19 pandemic, while highlighting the managerial implications of using digital technology in SMEs to deal with the impact of COVID-19 and secure business continuity [34]. Referring to the research results above, the hypothesis of this study is that the use of online applications has an effect on performance.

\section{Research Method}

The population is all Rujak UMKM in Jalan Pasar $7 \mathrm{Kab}$. Deli Serdang as many as 50 traders. The sample technique used is saturated sample so that the entire population is the sample of this study. This type of data uses primary data with data collection techniques using a questionnaire. The operational definitions of the variables are as follows:

1. Performance is a business performance consisting of financial performance and operational performance. The indicators used are "sales growth; customer growth; profit growth; working capital growth".

2. The use of online technology is the use of the go-food / grab-food online application. The indicators used in relation to online applications consist of, (1) Promotion and (2) Distribution.

The research model used is shown as follows:

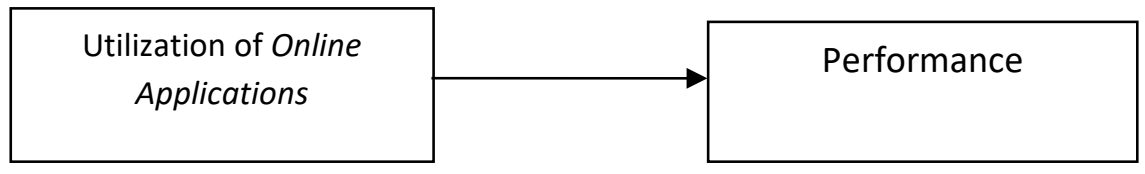

Fig 1. Research Model

The simple linear equation used is: $y=a+b x+e$. Data were analyzed using statistical descriptive analysis using simple linear regression. The steps taken are to first test the validity and reliability and test the new classical assumptions then carry out a simple linear regression test.

\section{Results and Discussion}

\subsection{Validity and Reliability Test}

The validity test can use the significance test by comparing the calculated $r$ value with the $\mathrm{r}$ table for degree of freedom $(\mathrm{df})=\mathrm{n}-2$ [35]. Based on this formula, $\mathrm{df}=34$ then the amount of df is obtained 34-2 = 32 and alpha 5\%. For df 32 and alpha 5\%, the $\mathrm{r}$ table is 0.2859 . Based on the results of the validity test using SPSS, it can be concluded that not all question items to measure each of the validity research variables, one indicator is invalid, namely the online application indicator (AO5), thus this indicator is ignored. The next step is 
to re-test the validity with the results that all indicators are declared valid and the data is suitable for further testing. After testing the validity, the next step is to test the reliability of the data by means of One Shot or just one measurement. The reliability test will use the existing facilities at SPSS with the Cronbach Alpha $(\alpha)$ test [35]A construct or variable is said to be reliable if it provides a Cronbach Alpha value $>0.70$ (Nunnally, 1994) in [35]Table 1 shows the complete validity and reliability test results that show all valid and reliable data.

Table 1 Validity and Reliability Test

\begin{tabular}{|c|c|c|c|c|c|c|}
\hline \multirow{2}{*}{$\begin{array}{c}\text { Indicat } \\
\text { or }\end{array}$} & \multicolumn{3}{|c|}{ Validity Test } & \multicolumn{3}{|c|}{ Reliability Test } \\
\hline & $\underset{\text { nt }}{r_{\text {_cou }}}$ & r_tabl & $\begin{array}{c}\text { Informati } \\
\text { on }\end{array}$ & $\begin{array}{c}\text { Cronbac } \\
\text { h's Alpha }\end{array}$ & $\begin{array}{l}\text { Criteri } \\
\text { a }\end{array}$ & $\begin{array}{c}\text { Informati } \\
\text { on }\end{array}$ \\
\hline $\mathrm{AO} 1$ & 0,7535 & 0.2869 & Valid & 0,8472 & $>0,07$ & Reliable \\
\hline $\mathrm{AO} 2$ & 0,7608 & 0.2869 & Valid & 0,8459 & $>0,07$ & Reliable \\
\hline $\mathrm{AO} 3$ & 0,6594 & 0.2869 & Valid & 0,8600 & $>0,07$ & Reliable \\
\hline $\mathrm{AO} 4$ & 0,6823 & 0.2869 & Valid & 0,8651 & $>0,07$ & Reliable \\
\hline AO6 & 0,7327 & 0.2869 & Valid & 0,8504 & $>0,07$ & Reliable \\
\hline $\mathrm{AO} 7$ & 0,7800 & 0.2869 & Valid & 0,8434 & $>0,07$ & Reliable \\
\hline $\mathrm{AO} 8$ & 0,3008 & 0.2869 & Valid & 0,8958 & $>0,07$ & Reliable \\
\hline K1 & 0,8023 & 0.2869 & Valid & 0,8259 & $>0,07$ & Reliable \\
\hline $\mathrm{K} 2$ & 0,8756 & 0.2869 & Valid & 0,8108 & $>0,07$ & Reliable \\
\hline K3 & 0,5719 & 0.2869 & Valid & 0,8865 & $>0,07$ & Reliable \\
\hline K4 & 0,7065 & 0.2869 & Valid & 0,8406 & $>0,07$ & Reliable \\
\hline K5 & 0,6501 & 0.2869 & Valid & 0,8560 & $>0,07$ & Reliable \\
\hline
\end{tabular}

\subsection{Data Normality Testing}

Normality testing can be done using graph analysis and statistical testing. Testing with statistics using the Kolmogorv Smirnov non-parametric test [35] This test refers to the Kolmogorv Smirnov value where if it has a probability greater than 0.05 , the variable is normally distributed [35]The following is complete information about the Kolmogrov Smirnov test can be seen in the table below:

Tabel 2 One-Sample Kolmogorov-Smirnov Test

\section{Unstandardized Residual}

$\mathrm{N}$

Normal

Mean

34

Parameters ${ }^{\mathrm{a}, \mathrm{b}}$

Std.

Deviation

.0000000

Most Extreme

Absolute

1.92353884

Differences

Positive

.072

Negative

Test Statistic

Asymp. Sig. (2-tailed) 
Based on the results of the data normality test using the Kolmogorov-Smirnov test, it can be concluded that the data in this study were normal distribution, as indicated by the Kolmogorov Smirnov value of 0.72 and a significance level of $0.200>0.05$. The results of Table 2 are also supported by graphic images. The normality test graph can be seen in Figure 2 below.

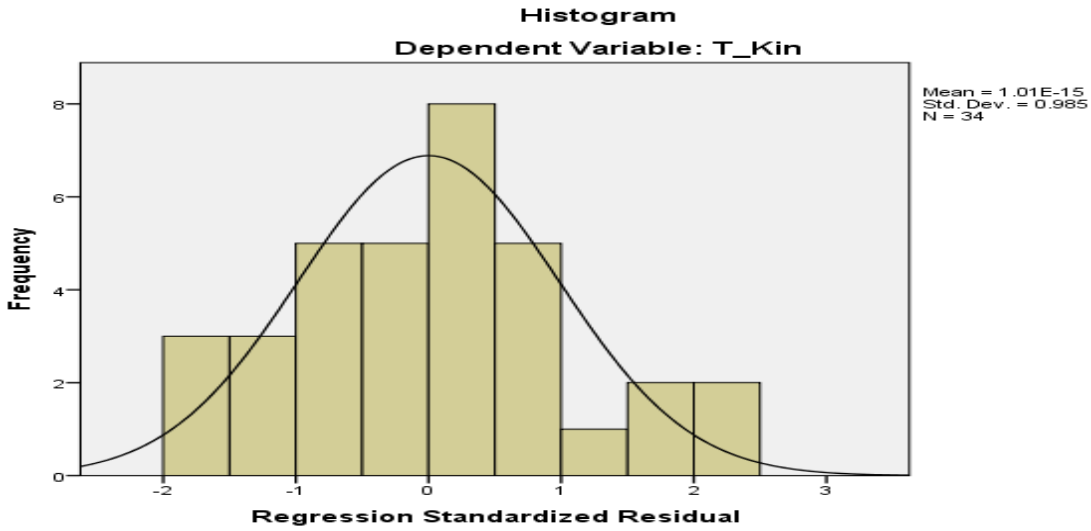

Fig. 2. Histogram

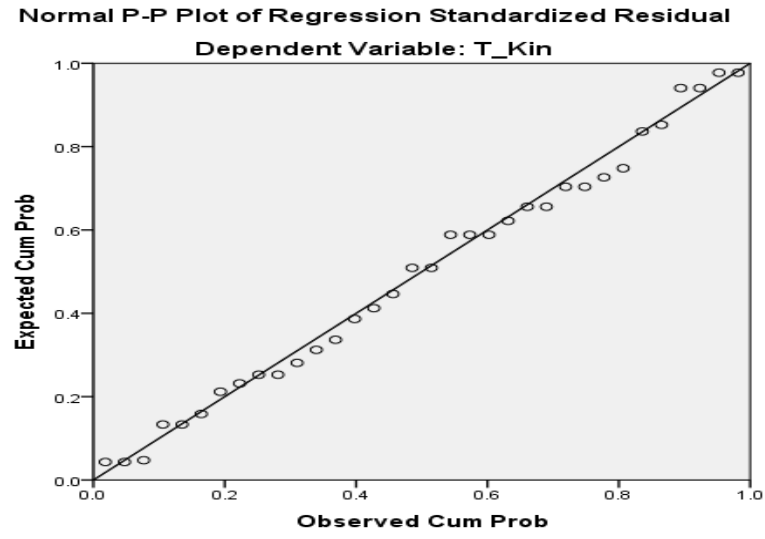

Fig. 3. Normal P-Plot

Based on the appearance of Figure 2, the histogram graph and the normal plot graph, it can be concluded that the histogram graph shows a balanced left and right skewness distribution pattern so that it can be concluded that the data is normally distributed. Meanwhile, if we refer to Figure 3, the normal plot graph shows that the points spread around the diagonal line, and the spread does not move away from the diagonal line, thus it can be concluded that the regression model has met the assumption of normality. This is in accordance with Ghozali [35],which states that if the data spreads around the diagonal line and follows the direction of the diagonal line or the histogram graph shows a normal distribution pattern, the regression model fulfills the assumption of normality.

\subsection{Heteroscedasticity Testing}


Based on the test results shown in Figure 4, it can be concluded that the data in this study are free from heteroscedasticity symptoms because the plot diagrams shown in the test do not show a certain pattern but are random. Ghozali [35] states that if there is a certain pattern, such as the existing dots forming a certain regular pattern (wavy, widened, then narrowed), it indicates heteroscedasticity has occurred.

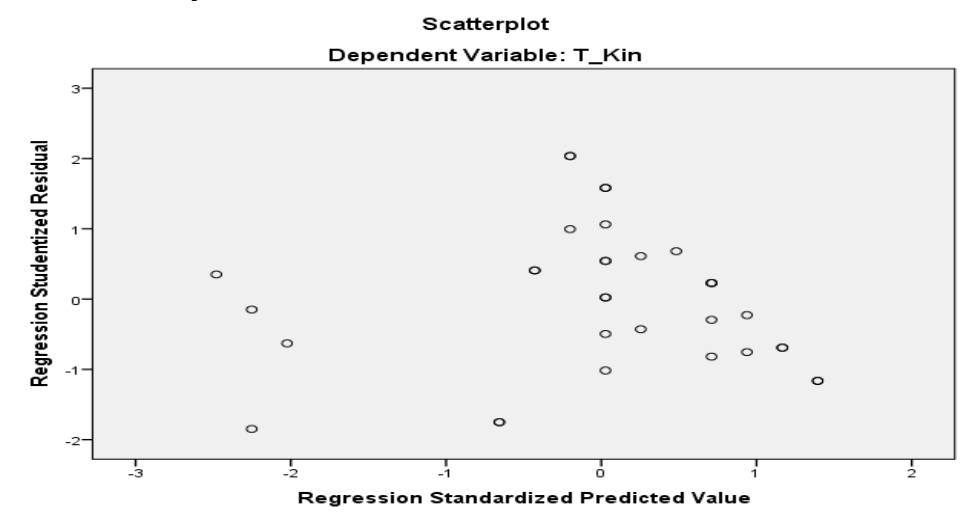

Fig. 4. Heteroscedasticity Testing

\subsection{Multicollinearity Testing}

Multicollinearity testing aims to test whether the regression model found a correlation between independent variables (independent). A good regression model should not have correlation between independent variables [35]. Measuring tools that are often used to measure the presence or absence of correlated variables using a test tool or Variance Inflation Factor (VIF) detection. Where the VIF value is not more than 10 and the tolerance value is not less than 0.1 [35]. In Table 3, it can be seen that of the independent variable the VIF value is not more than 10 and the tolerance value is not less than 0.1 . So it can be concluded in this regression model there is no multicollinearity problem.

Table 3. Multicollinearity Testing

\section{Variabel Tolerance Variance Inflation Factor}

\begin{tabular}{lrr} 
Online Aplication & 1,000 & 1,000 \\
\hline
\end{tabular}

\footnotetext{
4.5 Results of Data Analysis

Table 4 below shows the partial calculation results (t-count)
}

Table 4. Uji Hipotesis

\begin{tabular}{|c|c|c|c|c|c|c|c|}
\hline \multirow[b]{2}{*}{ Variabel } & & \multicolumn{2}{|c|}{$\begin{array}{c}\text { Unstandardized } \\
\text { Coefficients }\end{array}$} & \multirow{2}{*}{$\begin{array}{c}\begin{array}{r}\text { Standardized } \\
\text { Coefficients }\end{array} \\
\text { Beta } \\
\end{array}$} & \multirow[b]{2}{*}{$\mathbf{t}$} & \multirow[b]{2}{*}{ Sig. } & \multirow[t]{2}{*}{ Results } \\
\hline & & B & $\begin{array}{l}\text { Std. } \\
\text { Error }\end{array}$ & & & & \\
\hline \multirow{2}{*}{$\begin{array}{l}\text { Online } \\
\text { Aplication } \rightarrow \\
\text { Performance }\end{array}$} & (Constant) & $-1,298$ & 1,652 & &,- 786 & 438 & \multirow{2}{*}{$\begin{array}{l}\text { Positive } \\
\text { Influence }\end{array}$} \\
\hline & A_onl &, 869 &, 077 & ,893 & 11,218 &, 000 & \\
\hline
\end{tabular}


Hypothesis: there is an effect of using online applications on performance.

Testing with reference to the significance number in Table 5 shows the number 0.000 , so by comparing these results with $\alpha 5 \%, 0.000<0.05$ indicates that the use of online applications has a significant effect on performance. The use of online applications is able to explain the performance variable by $79.7 \%$. This value is obtained by referring to the $\mathrm{R}$ Square value according to Table 5 .

\begin{tabular}{c|c|c|c|c}
\hline Model & $\mathbf{R}$ & $\begin{array}{c}\text { R } \\
\text { Square }\end{array}$ & $\begin{array}{c}\text { Adjusted R } \\
\text { Square }\end{array}$ & $\begin{array}{c}\text { Std. Error of the } \\
\text { Estimate }\end{array}$ \\
\hline 1 & $.893^{\mathrm{a}}$ & .797 & .791 & 1.95336 \\
\hline
\end{tabular}

Based on the results of statistics, it shows that there is an effect of the use of the go-food / grab-food online application on performance during the Covid 19 pandemic. The Covid 19 pandemic causes the turnover of MSMEs to fall. The decline in turnover was also caused by the existence of government policies to stay at home and reduce activities outside the home, social distancing, lockdown / area quarantine that did not affect the turnover of MSMEs. In the end, MSMEs lose customers who buy directly. The presence of go-food or grab-food applications ultimately provides income for traders because they get new customers considering the far reach that this application can reach. Collaboration between MSME actors and vendors indirectly becomes a promotional event because the go-food or grab-food vendors will display information on their partners' businesses. Referring to the online application indicator, it is explained that the go-food or grab-food application is an effective promotional media for MSME players. Regarding distribution indicators, it can be explained that collaboration with go-food or grab-food application vendors in the end brings customers closer to the seller. The opening of new market shares where long distances are not an obstacle for customers to buy the desired product within the range of the application. Therefore, it can be concluded that utilizing go-food or grab-food applications is a means of distribution for sellers to deliver their products directly to customers without the need for customers to come to stores / outlets.

Another factor that causes the turnover to fall is a decrease in people's purchasing power, while the price of raw materials increases which in turn causes a decrease in profit margins because the selling price is fixed. Therefore, the use of online applications helps MSMEs in marketing / distribution, so that through online marketing, turnover can be increased by means of online promotion. Online promotion will expand market share and open up opportunities for new customers.

Based on the results of research, MSMEs using online applications have experienced growth in sales as a result of new customers using the go-food / grab-food online application features. The impact of new customer growth is the occurrence of sales transactions which are closely related to profit growth. When a sale occurs, it will have an impact on profit growth and working capital. The results of this study ultimately support previous research which states that the use of online applications will affect performance [27], [28], [29], [30], [31].

The practical implications of this study indicate that technology literate MSMEs that utilize online technology can be concluded to be able to survive in times of uncertainty. Referring to this conclusion, in the end, it provides an overview of the need for early guidance by related parties such as the local Cooperative and UMKM Service for MSMEs in their 
regions, especially awareness of the use of technology in helping their businesses, both for means of promotion, distribution, and transactions. This coaching will later be able to strengthen MSMEs to survive conditions of uncertainty such as what is happening today, namely the Covid-19 Pandemic. The use of online technology, one of which is the use of the go-food / grab-food online application, has finally become an alternative to survive the Covid19 pandemic. This application not only brings distant customers closer to outlets / stores but also becomes a new way to still generate revenue from business.

\section{Conclusion}

The conclusion of this study is that there is an effect of the use of the gofood / grab-food online application on the performance of MSMEs. Online applications are a means of promotion and distribution for MSMEs, resulting in the addition of new customers, sales growth, profits and capital. In the end, during the Covid-19 pandemic, the use of online applications was able to help MSMEs survive and continue their business. Therefore, it is important for related parties to provide guidance so that MSMEs are technology literate, especially online technology. MSMEs that are online technology literate will have the opportunity to expand market share because they are able to maximize technology either using online applications or maximizing social media such as Instagram, Facebook, WhatsApp and so on.

\section{Acknowledgments}

Acknowledgments. Thank you to the Politeknik Negeri Medan and the Ministry of Education and Culture for the research grants provided.

\section{References}

[1] R. Amelia, "Pengaruh Aplikasi Gofood Terhadap Peningkatan Penjualan Mochitalk Plaza Medan Fair," vol. 6, no. 2, pp. 79-84, 2019.

[2] A. Kuckertz et al., "Startups in times of crisis - A rapid response to the COVID-19 pandemic," J. Bus. Ventur. Insights, vol. 13, no. April, 2020, doi: 10.1016/j.jbvi.2020.e00169.

[3] K. Azhar and Z. Arifin, "Faktor-faktor Yang Mempengaruhi Penyerapan Tenaga Kerja Industri Manufaktur Besar dan Menengah Pada Tingkat Kabupaten/Kota di Jawa Timur," J. Ekon. Pembang., vol. 9, 2011.

[4] D. F. Suryadi and M. I. F. Ilyas, "Adopsi Online Food Delivery Service Bagi Wirausaha Pemula,” Ilmu Adm. Akuntansi, Bisnis, Dan Hum., vol. 2018, pp. 75-80, 2018.

[5] C. Lovelock, J. Wirtz, and Mussry, Pemasaran Jasa, Edisi 7. Jakarta: Erlangga, 2011.

[6] R. Shahjee, "The Impact of Electronic Commerce On Business Organization," An Int. peer Rev. Ref. Sch. Res. J. interdicilinary Stud., vol. 4, no. 27, pp. 3130-3140, 2016, [Online]. Available: https://www.google.com/url?sa=t\&rct=j\&q=\&esrc=s\&source=web\&cd=\&cad=rja\&uact=8\&ve $\mathrm{d}=2$ ahUKEwj7gIjH-

O3qAhX0yDgGHWJXB_YQFjALegQIBBAB\&url=http\%3A\%2F\%2Foaji.net\%2Farticles\%2F 2017\%2F1174-1484826380.pdf\&usg=AOvVaw1bAV9-QAAp8tR2mGNMqjwS.

[7] A. L. Fruhling and L. A. Digman, "The impact of electronic commerce on the supply chain," $J$. Electron. Commer. Res., vol. 17, no. 4, pp. 13-22, 2010, doi: 10.1108/bij.2010.13117daa.001. 
[8] Nurlinda, Wardayani, and I. Muda, "Factors Affecting e-Commerce Adoption on Micro, Small and Medium Enterprises in Medan City Factors Affecting e-Commerce Adoption on Micro , Small and Medium Enterprises in Medan City," in ICOSTEERR 2018 - International Conference of Science, Technology, Engineering, Environmental and Ramification Researches, 2020, no. August, pp. 1301-1311, doi: 10.5220/0010072313011311.

[9] N. Nurlinda et al., "Can E-Commerce Adoption Improve SME's Performance? (Case Studies on Micro, Small and Medium Enterprises with Gojek Services in Indonesia)," 2020, doi: 10.4108/eai.11-12-2019.2290850.

[10] I. Setiawati and P. Widyartati, "Pengaruh Strategi Pemasaran Online Terhadap Peningkatan Laba UMKM," Strateg. Komun. Pemasar., no. 20, pp. 1-5, 2017, [Online]. Available: file://C:/Users/BAYU/Downloads/Documents/263-760-1-PB.pdf.

[11] H. A. Mumtahana, S. Nita, and A. W. Tito, "Pemanfaatan Web E-Commerce untuk Meningkatkan Strategi Pemasaran," Khazanah Inform. J. Ilmu Komput. dan Inform., vol. 3, no. 1, p. 6, 2017, doi: 10.23917/khif.v3i1.3309.

[12] A. Indraswarri and H. Kusuma, "Analisa Pemanfaatan Aplikasi Go-Food Bagi Pendapatan Pemilik Usaha Rumah Makan Di Kelurahan Sawojajar Kota Malang,” J. Ilmu Ekon., vol. 2, pp. 63-73, 2018, [Online]. Available: http://ejournal.umm.ac.id/index.php/jie/article/view/6967.

[13] UU No 20, Undang-Undang Republik Indonesia Nomor 20 Tahun 2008 Tentang Usaha Mikro, Kecil dan Menengah, no. 1. 2008.

[14] F. Malcolm, "The Realities of Web-Based Electronic Commerce", Strategy \& Leadership," pp. 31-32, 1997.

[15] J. Papows, "Enterprise.com: Reading, MA: Perseus Books," 1998.

[16] F. C. Ling and L. Ting, "Assessment of Internet Marketing and Competitive Strategies for Leisure Farming Industry in Taiwan. J," ournal Am. Acad. Business. ISSN 15401200, vol. Volume 8, no. Issue 2, pp. 296-300, 2006.

[17] R. A. S. Peterson, Balasubramanian, and B. J. Bronnenberg, "Exploring the Implications of the Internet for Consumer Marketing," J. Acad. Mark. Sci., vol. Vol. 25, no. No. 4, p. hlm: 329-346, 1997.

[18] M. Y. Pratama, "Pengaruh Layanan Food Delivery Terhadap Peningkatan Penjualan pengusaha Kuliner (Studi Pada Pengusaha Kuliner Yang Terdapat di Go-Food/Go-Jek Jambi)," Universitas Islam Negeri Sulthan Thaha Saifuddin, 2018.

[19] R. Soleman, "Pengaruh Penganggaran Partisipatif terhadap Kinerja Manajerial Dengan Budaya Organisasi Dana Gaya Kepemimpinan Sebagai Variabel Moderating," J. Siasat Bisnis, vol. 16, no. 1, pp. 87-105, 2012.

[20] R. Supriyono, "Pengaruh Komitmen Organisasi dan Keinginan Sosial Terhadap Hubungan Antara Partisipasi Penganggaran Dan Kinerja Manajer," 2004

[21] J. Soininen, M. Martikainen, Puumalainen, and K. Kyläheiko, "Entrepreneurial orientation: Growth and profitability of Finnish small- and medium-sized enterprises," Int. J. Prod. Econ., vol. Vol. 140, no. No.,1, pp. 614-621., 2012.

[22] N. Venkatraman and V. Ramanujam, "Measurement of Business Performance in Strategy Research: A Comparison of Approaches," Acad. Manag. Rev., vol. 11, no. 4, pp. 801-814., 1986.

[23] I. G. Sidik, "Conceptual framework of factors affecting SME development: mediating factors on the relationship of entrepreneur traits and SME performance," 2012.

[24] Meutiaa and T. Ismail, "The Development of Entrepreneurial Social Competence And Business Network to Improve Competitive Advantage And Business Performance of Small Medium Sized Enterprises: A Case Study of Batik Industry In Indonesia," 2012.

[25] D. Tjondro and R. Wilopo, "Pengaruh Good Corporate Governance (GCG) terhadap Profitabilitas dan Kinerja Saham Perusahaan Perbankan yang Tercatat di Bursa Efek Indonesia," J. Bus. Bank., vol. 1, no. 1, pp. 1-14, 2011.

[26] Nurhadi, "Anteseden Penggunaan E-Commerce: Pengaruhnya Terhadap Manajemen Pengetahuan dan Kinerja Organisasi," Universitas Brawijaya, 2015.

[27] M. Wade, D. Johnston, and R. McClean, "'Exploring the net impact of internet business 
solution adoption on SME performance," Int. J. Electron. Bus., vol. 2, no. 4, pp. 336-350, 2004.

[28] E. Doherty, E. Ramsey, P. Harrigan, and P. Ibbotson, "Impact of Broadband Internet Technologies on Business Performance of Irish SMEs," Strateg. Chang., vol. 25, no. 1, pp. 693-716, 2016.

[29] Y. T. Arisandi, "Efektivitas Penerapan E-Commerce Dalam Perkembangan Usaha Kecil Menengah di Sentra Industri Sandal Dan Sepatu Wedor Kabupaten Sidoarjo . (Unpublished)," 2018.

[30] M. N. Utomo, "Efektivitas Bisnis Berbasis Teknologi Internet dalam Membangun Kinerja Kewirausahaan," BISMA (Bisnis dan Manajemen), vol. 11, no. 2, pp. 156-172, 2019.

[31] Misnawati and Yusriadi, "Efektifitas Pengelolaan Kewirausahaan Berbasis Kognitif Personal Melalui Penggunaan Infrastruktur Digital (Media Sosial)," Jurnam Mitra Manaj. (JMM Online), vol. 2, no. 3, pp. 138-145, 2018.

[32] F. Zulfikar and P. Supriyoso, "Efektifitas Penjualan Online Melalui Media Sosail Pada Perusahaan CV Billionaire Sinergi Korpora (Billionaire Store)," in Festival Riset Ilmiah Manajemen Akuntansi, 2019, pp. 909-913.

[33] N. N. Hartmann and B. Lussier, "Managing the sales force through the unexpected exogenous COVID-19 crisis," Ind. Mark. Manag., vol. 88, no. April, pp. 101-111, 2020, doi: 10.1016/j.indmarman.2020.05.005.

[34] T. Papadopoulos, K. N. Baltas, and M. E. Balta, "The use of digital technologies by small and medium enterprises during COVID-19: Implications for theory and practice," Int. J. Inf. Manage., no. June, p. 102192, 2020, doi: 10.1016/j.ijinfomgt.2020.102192.

[35] I. Ghozali, Aplikasi Analisis Multivariate Dengan Program IBM SPSS 23, VIII. Semarang: Badan Penerbit Universitas Diponegoro., 2016. 